\title{
日本の学校教育における環境教育と 土木学の教育の可能性についての考察
}

\author{
都筑 良明 1,2 \\ 1正会員 東洋大学期間雇用者（プロジェクト研究担当）（†374-0193 群馬県邑楽郡板倉町泉野1-1-1） \\ 2正会員 島根大学汽水域研究センター協力研究員（干690-8055 島根県松江市西川津町1060) \\ E-mail:tsuzuki.yoshiaki@gmail.com
}

\begin{abstract}
環境教育分野の既存文献のレビュー, 大学の環境関連授業受講生を対象とする小中高校における環境に ついての学習内容のアンケート調査および当時の学習指導要領についての検討により, 今後の環境教育の 方向性および土木学の教育との関連性について検討した. アンケート調査結果から, 知識や情報はある程 度習得したが, 理科, 社会の学習指導要領に記載されているような自然や環境の見方や考え方を習得した とは認識していなかったと考えられた。知識や情報に基づいて見方や考え方を養うという学習指導要領の 体系について, 教員側と生徒・学生側の双方で再確認寸る必要性等が考えられた。 土木学の教育と環境教 育との関連については, 部門 $\mathrm{B}, \mathrm{G}$ は大きく関連し, 他の部門も含めて環境教育や既存教科への題材提供 等について必要性も含めて検討すべきである.
\end{abstract}

Key Words : education of civil engineering, environmental education, Official Course of Study of Japan, knowledge and information, watching and thinking ways on nature and environment

\section{1. はじめに}

近年，環境基本法，環境教育推進法が制定され，学習 指導要領や教科書にも環境教育に関する内容が増えてき ている. 小中高校，大学の学校教育における環境教育に 関する様々な試みも報告されている．現在の教育体系は， 大まかには就学前, 小中高校, 大学に分けて考えること ができる．教育を受ける側から考えた場合には，小中高 校の学校教育における環境教育の成果が, 大学, 社会に おいて，どのように活かされているかを整理，把握する ことも重要である.

筆者は先に，環境教育をテーマとするテキストを取り まとめた1).土木学会の教育論集発刊の案内を择見し, 環境教育と土木学の教育について検討寸る良い機会と考 え，前述のテキスト1)等を基に本論を執筆した.

本論では，小中高校および大学を含む学校教育におけ る環境教育の現状等に関する既往の研究について, 環境 教育誌，環境情報科学誌上に最近約 20 年間に発表された 研究成果を中心にレビューした，海外については，世界 における環境教育の展開の概要とアメリカ等の環境教育 についてレビューした．以上の文献レビューにおいては, 本論の1つの中心部分である小中高校における環境に関 寸る教育についての大学生による認識と, 当時の学習指 導要領との比較検討をテーマとする論文等の有無につい
て注目したが，そのようなテーマの既存文献は見当たら なかった。

次に，大学生による小中高校における環境分野の教育 についての認識をアンケート調査により検討した．さら に, アンケート調査の結果と大学生が小中高校生であっ た当時の学習指導要領の内容と比較検討した2),3). これら の検討結果に基づき，今後の環境教育の方向性について 考察した. さらに, 土木学の教育の学校教育における方 向性を考えるためには，環境教育や既存の教科との関係 を検討することが重要と考え，土木学の教育と既存の教 科およひ環境教育との関係について整理，検討した。本 稿のうち, 第2章は前述の限定配布されたテキスト ${ }^{1)} の$ 構 成を見直したものである. 環境教育分野のレビューは, 土木学の教育を考える上でも有用な情報が含まれている と考え, 本稿の一部とした.

既発表の論文との関係を整理すると，レビュー部分に ついては都筑をを精查し, アンケート調査 ${ }^{2 / 3}$ の結果と学 習指導要領の内容との比較検討に基づく検討の部分につ いては，都筑3の検討結果を精査した.

\section{2. 環境教育の現状 ${ }^{1)}$}

(1) 日本における環境教育の経緯についてのいくつかの 側面 
環境に関する内容が小中高校での教育に取り入れられ たのは比較的新しいことである．昭和 40～50 年代には 四大公害病が環境に関する主な内容であった。環境教育 の重要性は，1970（昭和 45）年代から認識されてきた。 品田 ${ }^{4)}$ は昭和 51 （1976）年度文部省特定研究「都市生態 系の構造と動態に関する基礎的研究」（代表者・沼田真 千葉大学教授）において，縄文，弥生の人々の生活パタ 一ン，奈良時代以降の都市化と自然をなつかしむ意識に つい考察し，地域と自然への接触行動との関係につい て，自然が失われている地域では，より外側に自然を求 めること，ヨーロッパにおいても都市の規模と自然を鑑 賞するといら行動が関係していることを指摘し，視覚の 波長に対する感受性から緑に触れる重要性を指摘した.

日本環境協会 ${ }^{5)}$ は昭和 56～57（1981～82）年度における 環境教育の現状を，「環境教育が必要であることはある 程度広く認識されているものの, 具体的な『カリキュラ ムづくり』についてはほとんど手がつけられていない」 状況であるとした。同協会は昭和 58（1983）年度に小 中学校における環境教育のカリキュラム作成についての 実証的研究を開始した. 島津 ${ }^{9}$ は大学院における環境学 について, SMLES (seamless earth science シームレス地球 科学または simulation earth science シミュレーション地球 科学) 研究グループでの議論の流れに触れながら, 学問 中心と目的中心，システム制御とシステム・マネジメン 卜等の考え方について，環境学ではいずれも後者の考え 方が重要であるとした。 さらに, SMLES から $E^{3}$ (earth science-ecology-economy) environmentology（<地球科学一 生態学一経済学>「環境学」）へと考え方が発展してき たことを述べ「環境学」ではマクロ「環境学」とミク ロ「環境学」が相補的に必要であるとした．沼田 7 や小 川 ${ }^{8)}$ が指摘するように，小中高校から大学の学校教育の 体系の中で, 環境教育の一体化や系統化を図ることも重 要であると考えられる.

以上のように，環境教育を考える軸として，公害と環 境, 関連法・制度とカリキュラム・実践 5,7,8), 都市と地 方 ${ }^{4)}$, 学問中心と目的中心 ${ }^{9}$, マクロ環境学とミクロ環 境学 等があり, 学校教育における体系化も課題とされ てきた.

\section{（2）小中高校における環境教育}

小学校における環境教育については, 理科教育を中心 とする展望と実践 9)，学校裁量時間を活用した実践活動 10), 総合的な学習における学校ビオトープやふるさと学 習 ${ }^{11)}$ ，小学校における身近な動植物とのかかわりを重視 した体験活動 ${ }^{12)}$ ，小学校における地域や行政との公園作 りにおける協働 ${ }^{13)}$ ，小学校における棚田を題材にした体 験学習 ${ }^{14)}$, 埼玉県内の公立小学校を対象とする実態調査

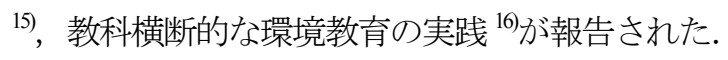

中学校における環境教育については，琵琶湖を素材と する理科, 社会, 家庭科教育の実践 ${ }^{17)}$, 学校放送番組を 活用した実践 ${ }^{18)}$ ，学校ビオトープを活用した自然環境教 育に関する検討 ${ }^{19)}$ ，理科におけるアクションリサーチに よる環境教育授業の実践的研究 ${ }^{20)}$, 家庭科の調理 ${ }^{21)}$, 家 庭科における全国レベルのアンケート調査結果 ${ }^{22)}$, エコ フィッシュによる河川浄化活動に関するアンケート調査 結果 ${ }^{23)}$, 河川環境改善の提案を設計する高校の授業の試 み 24)，エネルギ一環境 ${ }^{25)}$ ，LCA 的な考え方を取り入れ た教材作成と実践 ${ }^{20)}$ 等が報告された. 安田・山本 ${ }^{27}$ は, 中学校における環境教育の重要な点として，(1)学校一 の権限をもつ校長先生の理解，(2)教員の役職に関係な く参画できること, (3)学校行事への環境教育の導入, (4)「先生=仕掛ける人, 生徒=発展・実行させていく 人」への教育方法の転換，(5)「環境」という大きなテ 一マを身近な活動へ置き換える工夫（リサイクル活動の 考え方），(6)キーパーソン無しでも継続していける体 制作り，(7)人と人との「つながりづくり」，(8)環境教 育への森林体験導入の有効性, (9)地域との連帯（環境 教育の連鎖）を挙げた.

高等学校における環境教育については, 中尾 ${ }^{28)}$ は地理 における環境教育を整理し，森林をテーマにした実践事 例を報告した．環境教育誌における 2002～03 年の高等 学校の環境教育をテーマとする特集においては, 同誌上 の高等学校における環境教育に関する調査研究報告のと りまとめ ${ }^{29)}$, 環境診断マップ等を含む現代社会での実践 例 ${ }^{30)}$, 理数科における自然科学探求講座や高大連携特別 授業 ${ }^{31)}$, 炭焼き活動, 植物教材開発等の地域における環 境教育活動 ${ }^{32)}$, 高校生物で活用できる窒素, リンの分析 方法 ${ }^{33)}$ ，選択科目としての環境科学や総合的な学習の時 間におけるカリキュラム作成と実践 ${ }^{34)}$ ，学校設定科目

「郷土」における 1847 年善光寺地震を対象とする地域 の自然を学ぶ試み ${ }^{35}$, 高校生物における土袞浄化機能等 に関する実践的教育 ${ }^{36}$, 調理に関する環境意識にはマス コミと学校の授業の影響が比較的大きかったこと ${ }^{37)}$ 等の 報告が行われた. 高等学校における課題としては, 先進 的な取り組みが行われている高等学校におけるエネルギ 一，ごみ，生物多様性等についてのカリキュラム作り ${ }^{30)}$, 理数科の環境教育における特進クラスとしての期待と環 境教育の内容の充実の両立や自然科学的内容と社会科学 的内容との融合 ${ }^{31)}$ が指摘された.

小中高校におけるカリキュラムの横断化について, 加 藤 ${ }^{38)}$ は高校生物と高校倫理の学習指導要領および教科書 における環境教育関連事項を昭和 22 年から平成 11 年ま で整理した結果，生物と倫理のクロスカリキュラムの可 能性について双方からの働きかけが望まれるとした. 上 
杉・甲斐 ${ }^{39}$ は家庭科単独カリキュラム群と他の教科を含 む関連的カリキュラム群とにおける同一題材の授業につ いての比較分析を行い，関連的カリキュラム群のほうが, 環境や衛生に配慮した実践的な態度や物に対する価值観 の変容において有効性が認められたことを報告した。こ れらの新しい試みは，環境教育と既存教科との関係につ いての検討の必要性を示すものであり, 環境教育の方向 性を考える上で重要である.

\section{(3) 学校教科書における環境教育}

垂沢 ${ }^{40)}$ は小中学校の全教科の教科書について環境学習 の指導に関する内容の検討結果と授業での実践例を基に, 都市化の流れの中での環境教育の課題として，(1)児童 の生活スタイルの変化と関連付け，(2)素材の選定・精 選，(3)学校と家庭，(4)地域への愛着を挙げた．藤井 ${ }^{41)}$ は生物, 現代社会の教科書における森林に関する記述に 関する調査結果と，森林についての認識に関する高校生， 大学生を対象とするアンケート調査結果を基に, (1)教 科書の記述が学生の森林理解に寄与していること，(2) 今後は持続可能な森林経営, 間伐材の重要性を含む日本 の森林の特異性や広い意味での資源という視点からの森 林について記述することや，授業において取り上げるこ とが重要であることを指摘した．加藤 ${ }^{38)}$ は生物では生物 資源の保護の目的が「利用 $\rightarrow$ 生命尊重 $\rightarrow$ 環境保全」と移 り変わってきたこと，倫理では対象が対人間から対自然 へと変遷しているとし，特に平成元年から「生態系の一 員」といら記述が見られるようになったことを指摘した。 土屋・山口 ${ }^{42)}$ は家庭科教科書における環境関連の掲載内 容の 1980 年代からの変遷について検討し, 1989 年の学 習指導要領の改訂後に記述が増加したことを指摘した.

\section{(4) 大学における環境教育}

大学における環境教育について，半谷 ${ }^{43}$ は環境科学課 程の可能性について論じ，具体的な講義科目として， (1)環境破壊の原因の解析，(2)環境の評価の方法，(3)環 境の歴史，(4)システム論と相関解析論，(5)意思決定方 法論, (6)研究組織論と総合研究方法論, (7)専門課題, を挙げた. 綾野 ${ }^{44)}$ はニューヨーク州立大学環境科学森林 カレッジにおけるフレキシブルな環境科学大学院を紹介 し, 複雑に関連した環境問題への大学院レベルでの対応 が必要であることを述べた。2002 年には大学環境教育 研究会が環境教育誌で発足 10 年目のシンポジウムにつ いて報告し，これまでの経緯と今後の課題を様々な視点

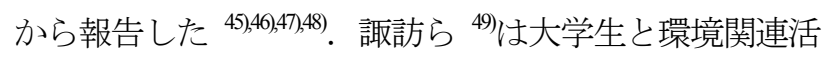
動を行っている市民の環境意識をアンケート調査と統計 解析により分析し，後者の環境意識の方が高いことを示 した，大学院における環境教育について，Uchiyama ${ }^{50)}$ は
「環境」がコース名に含まれる環境冠コースの変遷をま とめており，環境冠コースが 1975～80 年および 1990 年 以降に増加していることを示した.

土木学会では, 環境システム委員会において, 学校教 育に限らない環境関連事項の俯瞰的・包括的な視点，総 合・横断型研究開発の体制の確立を視野に入れた検討も 行われた ${ }^{51)}$.

\section{（5）環境教育に関する日本の政策と情報化}

環境教育の内容が政策レベルでどのように決定され， さらには学校現場でどのように実施されているかについ て検証することは重要であると考えられる．環境教育に 関する政策について，谷口 ${ }^{52}$ は，環境基本計画の枠組み に関連するパートナーシップによる環境教育と環境学習 についての考え方を整理した．高橋・井村 ${ }^{53}$ は日本にお ける環境教育政策の決定要因について，(1)1967 年に制 定された公害対策基本法の中ではじめて制度化された公 害教育，(2)1993 年に制定された環境基本法の中に位置 付けられた環境教育，(3)2003 年に制定された環境教育 推進法が定めた環境教育，の 3 種類の環境教育について の専門家へのヒアリングとモデルによる検討の結果, こ れら 3 つの環境教育政策の策定要因が異なっていたこと を示した. ヨハネスブルックサミットで日本が提唱した 「持続可能な開発のための教育の 10 年」の取り組みに 関連した環境教育についての検討も行われてきた ${ }^{54)}$.

情報化の進展の流れの中で，環境教育における活用に 際しての問題点が検討され ${ }^{55)}$ ，インターネット上で活用 できる環境教育関連の情報整備も進められてきた ${ }^{56,577}$.

\section{（6）海外における環境教育}

国際的には，ユネスコが中心となり 1975 年の国際環 境教育会議（ユーゴスラビア，ベオグラード），1977 年の環境教育政府間会議（ソ連グルジア共和国, トビリ シ）で環境教育をテーマとする議論が行われ，それぞれ， ベオグラード憲章，トビリシ宣言が発表された ${ }^{58) 59)}$. 諸 外国については，1990 年頃の東ドイツ，イギリスにお ける学校教育, 生涯教育における環境教育についての視 察結果に基づき，日本では環境教育の拠点整備，民間環 境保全団体の育成, 情操教育, 国際交流が必要であると された ${ }^{60)}$. 海外では, 諸条件が各国で異なるため, 環境 教育の内容も様々である ${ }^{61)}$. オーストラリア・ヴィクト リア州における後期中等教育段階の環境教育 ${ }^{62)}$, 日本と マレーシアの理科教師を対象とする環境教育についての アンケート調査 ${ }^{63)}$, 中国の小中学校における環境教育の 現状 ${ }^{64)}$ が報告された. インドでは NGO を中心とする環 境教育も行われている ${ }^{65)}$. 日本と諸外国の教科書におけ る環境教育について，朴 ${ }^{60}$ はドイツ，中国，韓国の教科 
表-1 履修学生の学年と年度の関係 ${ }^{\text {注1) }}$ (都筑 ${ }^{3)}$ を修正)

\begin{tabular}{|c|c|c|c|c|c|c|c|c|c|c|c|c|c|c|c|c|}
\hline \multirow{3}{*}{ 学年 ${ }^{2)}$} & \multicolumn{2}{|c|}{ 昭和 } & \multicolumn{14}{|c|}{ 平成 } \\
\hline & 62 & 63 & 元 & 2 & 3 & 4 & 5 & 6 & 7 & 8 & 9 & 10 & 11 & 12 & 13 & 14 \\
\hline & 1987 & 88 & 89 & 90 & 91 & 92 & 93 & 94 & 95 & 96 & 97 & 98 & 99 & 2000 & 1 & 2 \\
\hline 2 & & & $\overline{\bar{E}}$ & 2 & 3 & $\bar{~} 4$ & $\bar{~} \overline{5}$ & 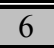 & $\overline{\mathrm{J} \text { J1 }}$ & 2 & 3 & 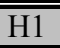 & 2 & 3 & 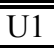 & $\overline{2}$ \\
\hline 3 & & E1 & 2 & 3 & 4 & 5 & 6 & $\mathrm{~J} 1$ & 2 & 3 & H1 & 2 & 3 & U1 & 2 & 3 \\
\hline 4 & E1 & 2 & 3 & 4 & 5 & 6 & $\mathrm{~J} 1$ & 2 & 3 & $\mathrm{H} 1$ & 2 & 3 & $\mathrm{U} 1$ & 2 & 3 & 4 \\
\hline
\end{tabular}

注1) $\mathrm{E}$ : 小学校, $\mathrm{J}$ : 中学校, $\mathrm{H}$ : 高等学校, $\mathrm{U}$ : 大学;2) 平成14(2002)年度の学年. 留年, 浪人等は考慮していない;3) 網掛け は, 学習指導要領の対象年次を示す.

書についての比較検討を行い, 蘇らのは日本と中国の地 理の学習指導要領と教科書の記述に関して比較検討した. 井元 ${ }^{8}{ }^{8}$ は日英の家庭科教科書における環境教育に関する 比較検討を行い，英国の教科書では日常生活において環 境意識を持ちながら主体的に行動することの重要性が書 かれていること等を指摘した。

アメリカでは 1920 年頃から国立公園，インタープリ ターによる様々な自然に親しむプログラム, 都市公園の 整備が進められ，広大な国土において自然を克服すべき 対象と考える地域が多く, 環境教育法が制定された 1970 年以降に動植物に関する様々なテキストが整備さ れ, 1980 年頃には学校の理科や社会の教科では体験学 習に重点が置かれる一方で, 環境教育は教科横断的なプ ログラムであったために成果を数字で示寸ことが困難で, 予算が次々と減額された ${ }^{69}$. 1981 年に環境教育法が廃 止されたのは, 都市住民を中心にアウトドア志向が根強 い等，環境教育の内容が既に社会の中に組み込まれてい たために学校教育における環境教育の重要性が一時的に 低下したものだが，1990 年には環境教育推進のための 連邦政府組織の充実，財団，基金，表彰制度，情報網等 の具体的取り組みを定めた新環境教育法が制定された ${ }^{58)}$. 日米の環境教育に関する考え方の違いを示すものとして, アメリカでは川魚の一種が絶滅の危機に瀕したためにダ ムの計画が中止になった事例がある一方で，日本では木 タルや魚類などの養殖・放流が行われ，遺伝的に同じ系 統の生物種が全国的にばらまかれ，種の天然分布と地域 固有種集団（地方ポピュレーション）の保存が危ぶまれ ていると考えられた ${ }^{58)}$.

\section{（7）社会における環境教育}

前項で述べたアメリカにおける学校および社会におけ る環境教育に関する状況 ${ }^{69}$ を参考にすると，環境教育に ついて学校教育と社会における教育とを合わせて考える ことが重要であると考えられる，環境教育，環境倫理と いう考え方は欧米の民主主義の歴史を通して生まれてき たものであり, 日本では日本型の環境教育, 環境倫理が 必要であるという考え方もある ${ }^{70}$. NGO などによる環 境保護運動は，自然保護の普及活動に参加し，環境保全 に関する行政，法制度の限界や自然破壊が起こる社会的
表-2 昭和 52 年以降の学習指導要領の改訂の状況 (都筑 ${ }^{3)}$ 修正)

\begin{tabular}{|c|c|c|c|}
\hline \multicolumn{2}{|c|}{ 小学校, 中学校 } & \multicolumn{2}{|c|}{ 高等学校 } \\
\hline 改訂 & 施行 & 改訂 & 施行 \\
\hline \hline 昭和52年度 & 昭和55年4月 & 昭和53年度 & 昭和57年4月 \\
\hline 平成元年度 & 平成4年4月 & 平成元年度 & 平成4年4月 \\
\hline 平成10年度 & 平成14年4月 & 平成10年度 & 平成15年4月 \\
\hline
\end{tabular}

注1) 網掛けは, 対象とする学習指導要領を示す.

仕組みなどを学習し，より良い環境像を模索・選択・創 造する活動を一般市民が自主的に行っているという点で, ストックホルム会議の行動計画やベオグラード憲章に適 合した活動をしているという見方が示された ${ }^{58)}$. 日本に おいても拠点づくりや行政，市民向けの情報ネットワー クの形成が試みられてきた ${ }^{71}$. 最近では, 博物館におい て市民参加の環境教育演習等も行われている ${ }^{72}$.

\section{（8）小中高校と大学における環境教育}

大学での教育においても, 現在の様々な環境問題に及 ぼす一般市民生活の影響が大きくなっているため, 職業 人および一般市民として，環境や持続可能性について考 える基礎を育成することも必要である. 小中高校の環境 に関する学習内容や方法が, 時代や場所により変化して きているため, 学生が小中高校で環境についてどのよう なことを学習, 経験してきたかを把握することも重要で ある.しかしながら, 文献レビューの結果では, 学習指 導要領, 教科書を対象とする研究はあったが, 学習指導 要領の内容と大学生の小中高校における環境に関する学 習内容についての認識との比較検討や，小学校から高等 学校までの学習指導要領を検討した研究は見当たらず, これらの点についての検討は意義があると考えられた.

\section{3. 大学生による小中高校における環境分野の教育 についての認識2),3)}

\section{(1) アンケート調査と学習指導要領の検討}

地球環境論, 国際環境協力論の受講生を対象に行った アンケート調査の中から，「これまで，地球環境（また は国際環境協力）について，1)大学，2)高校，3)中学校, 4)小学校およびそれ以前，の各時期にごのようなことを 学んできましたか」という設問の回答結果について検討 した ${ }^{2,3)}$. 履修学生が小中高校だった年度の文部科学省 
表-3 学習指導要領に記載があり, アンケート回答になかっ た項目の例（小中学校分） (都筑 ${ }^{3)}$ を修正)

\begin{tabular}{|c|c|}
\hline 学校 & \multirow{3}{*}{ 内容 } \\
\hline 学年 & \\
\hline (年) ${ }^{2)}$ & \\
\hline 示学校 & 社会 \\
\hline $\begin{array}{c}\text { 年 } \\
(\mathrm{S} 52)\end{array}$ & 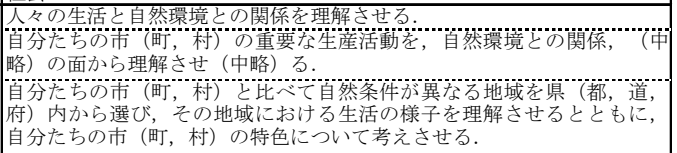 \\
\hline $\begin{array}{l}4 \text { 年 } \\
\text { (S52) }\end{array}$ & $\begin{array}{l}\text { 人々が様々な地域において自然環境に適応しながら生活している様子に } \\
\text { 関心をせる. }\end{array}$ \\
\hline $\begin{array}{l}\text { 年 } \\
(\mathrm{S} 52)\end{array}$ & 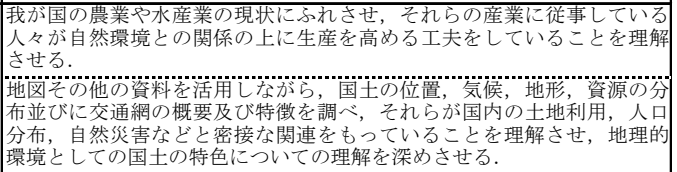 \\
\hline $\begin{array}{c}4 \text { 年 } \\
\text { (H元) }\end{array}$ & 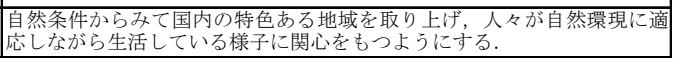 \\
\hline $\begin{array}{c}5 \text { 年 } \\
(\mathrm{H} \text { 元 })\end{array}$ & $\begin{array}{l}\text { 国土の保全や水資源の涵（かん）養などのために森林資源が大切である } \\
\text { ことに気付くようにする. }\end{array}$ \\
\hline 示学校 & 理科 \\
\hline $\begin{array}{l}1 \text { 年 } \\
\text { (S52) }\end{array}$ & 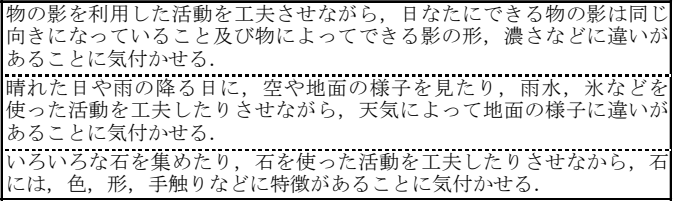 \\
\hline $\begin{array}{l}\text { 2年 } \\
(\mathrm{S} 52)\end{array}$ & 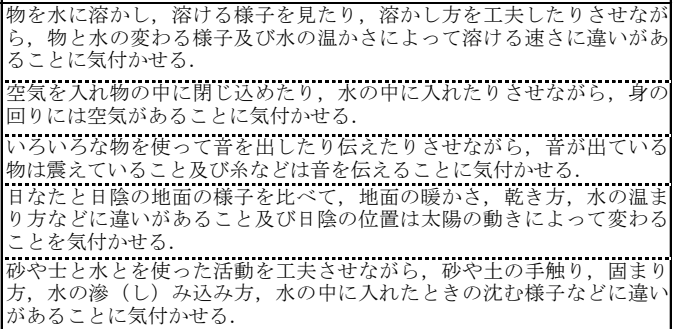 \\
\hline $\begin{array}{l}\text { 年 } \\
(\mathrm{S} 52)\end{array}$ & 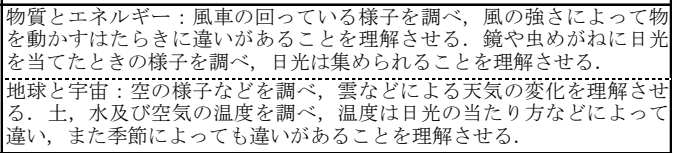 \\
\hline $\begin{array}{l}4 \text { 年 } \\
(\mathrm{S} 52) \\
\end{array}$ & $\begin{array}{l}\text { 地球と宇宙：雨水が地面を流れる様子及び川原や川岸の様子を調べ, 流 } \\
\text { れる水のはたらきを理解させ } \\
\end{array}$ \\
\hline $\begin{array}{c}\text { 年 } \\
(\mathrm{H} \text { 元 })\end{array}$ & 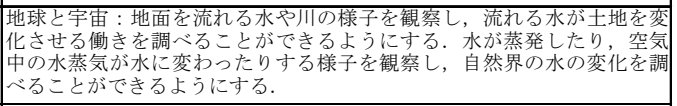 \\
\hline $\begin{array}{l}\text { 年 } \\
(\mathrm{H} \text { 元 })\end{array}$ & 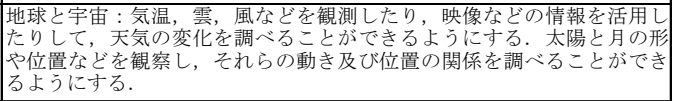 \\
\hline $\begin{array}{l}6 \text { 年 } \\
(\mathrm{S} 52)\end{array}$ & 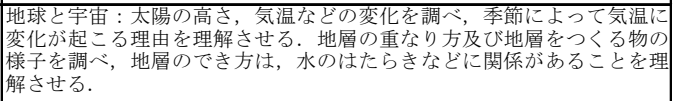 \\
\hline $\begin{array}{c}\text { 年 } \\
(\mathrm{H} \text { 元 })\end{array}$ & $\begin{array}{l}\text { 地球と宇宙：地層や岩石などを観察し，土地をつくっている物の特徵や } \\
\text { 土地のでき方を調べることがきるる。 }\end{array}$ \\
\hline 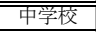 & 社会 \\
\hline $\begin{array}{c}\text { 地理的分 } \\
\text { 野 } \\
(\mathrm{H} \text { 元 })\end{array}$ & 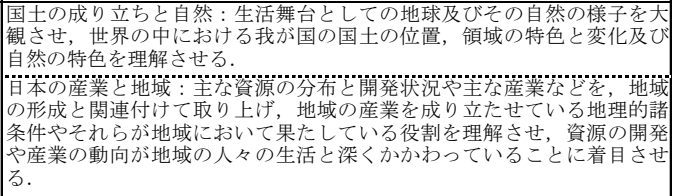 \\
\hline $\begin{array}{c}\text { 歴史的分 } \\
\text { 野 } \\
(\mathrm{H} \text { 元 })\end{array}$ & 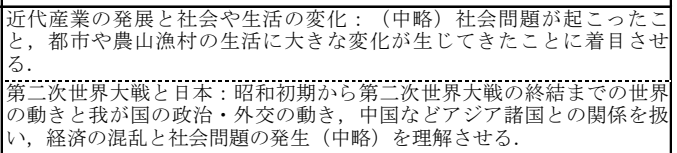 \\
\hline 小 & $\begin{array}{l}\text { 学校分を集計した. 高等学校分については, 図1に記載した；2）学習指導 } \\
\text { 年度. }\end{array}$ \\
\hline
\end{tabular}

の学習指導要領の内容について調査した ${ }^{3)}$. 履修学生は 大学の 2〜4 年生であったので，調査対象は表-1 に示す ように原則として昭和 62（1987）年度以降とした。こ の期間の学習指導要領は表-2 に示すような改訂が行われ
ていた ${ }^{73)}$. 表-1，2 から小学校については昭和 52 年度お よび平成元年度, 中学校, 高等学校については平成元年 度の学習指導要領を検討した. 検討対象の教科は, 小学 校, 中学校の社会, 理科と, 高等学校の地理歴史, 公民, 理科とし, 小学校の平成元年度学習指導要領については 4〜6年次を対象とした.

\section{(2) アンケート回答と学習指導要領の内容との比較}

アンケート回答の詳細については既報 ${ }^{233}$ を参照して いただきたい，ここでは，高等学校の結果を中心に概説 する（図-1）。図中の下線部は学習指導要領に記述があ る内容である.

アンケート回答と学習指導要領の両方に含まれている 内容は, 回答した学生にとって学習・教育効果があった と判断した，学習指導要領に記載はないが，アンケート 回答に含まれていた項目については，他の教科も含めて 教科書に記載されていた，授業で扱った，他の教科で扱 った, 課外活動で学習した, 学校外で学習, 経験した等 の可能性が考えられた.

学習指導要領に記載されているが，アンケートの回答 には含まれていなかった内容の例を，小中学校分につい て表-3に示寸。これらの内容がアンケートの回答に含ま れなかった原因としては，(1)何らかの理由で学習・教 育が行われていなかった，(2)教育は行われていたが学 生が認識していなかった，または回答するほど印象には なかった，(3)学生にとって「環境」とは関連付けて認 識されていなかった等が考えられた.

\section{(3) 学習指導要領における環境教育}

学習指導要領は, 昭和 52 年の改訂から環境教育に関 寸る内容が各教科で充実してきた ${ }^{74)}$ ．文部省は平成 3

（1992）年に中高校向けの環境教育指導資料，平成 4

（1993）年に小学校向けの環境教育指導資料を刊行し, 特定の教科ではなく, すべての教科で環境教育に取り組 む方針を示した ${ }^{59775)}$. 各教科・科目の指導を，単なる知 識の伝達から, 自ら学び, 考え, 判断できる学習への質 的な転換を図ることが必要であり，環境教育を通して身 につけることができる能力としては，(1)問題解決能力, (2)数理的能力, (3)情報活用能力, (4)コミュニケーショ ン能力, (5)環境を評価する能力, (6)主体的な思考, (7) 社会的な態度, (8)他人の信念, 意見に対寸る寛容, が 指摘された ${ }^{58}$. 従来は，自然についての教育や自然を愛 護する教育を肯定し，具体的な自然を守ることや環境問 題解決のための社会的問題に関わることについては政治 的，運動などと考えられて否定的な部分もあったが，平 成 2（1991）年の環境教育指導資料では, 社会経済の仕 組みを環境に配慮したものへと変革していくことや，よ 
り良い環境の創造活動に主体的に参加するという国際的 概念が環境教育の理念として取り入れられた ${ }^{58)}$.さらに, 環境教育推進法制定に伴い，環境科などの独立した環境 教育教科の必要性も提案された.

\section{(4) アンケート調査結果と学習指導要領との比較検討}

表-3 および図-1 の上部に見られるように，学習指導要 領には，見方や考え方を養うという多くの記述がある. しかしながら，見方や考え方といらアンケート回答はな かった. この点については, 設問に問題があった可能性

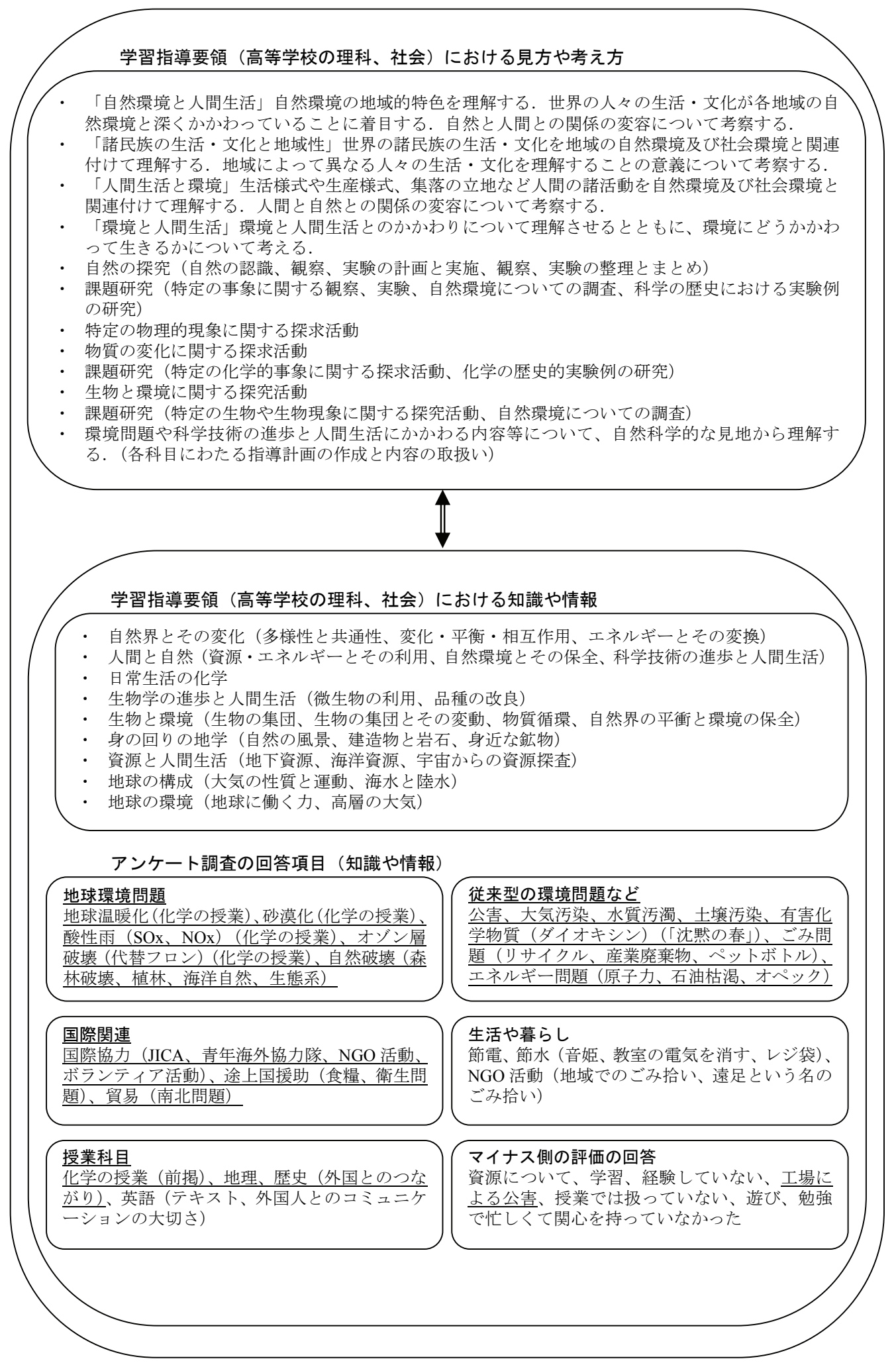

図-1 アンケートに回答した大学生が高等学校で学習した環境関連の内容と，高等学校の学習指導要領における「知識や情 報」と「見方や考え方」との関連図. 下線部は学習指導要領に記述があることを示寸．今後の課題として，これらの 関連を教える側, 教わる側が認識し, 学習することが考えられる.（アンケート回答と学習指導要領調査結果を基に 作成した） (都筑 ${ }^{3}$ を修正) 
もあるが，アンケートに回答した学生は見方や考え方を 学習したとは意識していなかったとも考えられる. 本論 では, 後者の考え方に基づき, 以下の議論を進める. 前 者については今後の検討課題としたい.

見方や考え方を養うためには，基礎となる知識や情報 が必要であると考えられ，アンケート回答 2,3) と表-3 を 基にして図-1を作成した. アンケート調査結果および学 習指導要領についての検討結果から，知識や情報を基に， 見方や考え方を習得するという理科, 社会の学習指導要 領の体系を, 教える側, 教わる側の双方が理解寸る必要 があると考えられた。 これは，学習指導要領の内容を理 解することにより, 学習効果が増すものと考えられるか らである. 近年の高等教育において, シラバスが学生等 に公開される傾向があるのは，類似の良い例であると考 えられる. そのためには，例えば，小中学生向けには学 習指導要領の内容を分かり易く表現した文章を作成する, 高校生向けには学習指導要領の本文を提示して学習の敉 らいを理解させるというような方法も有効であろう.

環境問題は自然科学, 社会科学の両方の側面からます ます複雑さを増していると考えられ，小中高校を含む学 校教育においても，従来は暗記科目とも考えられていた 社会, 理科教育や総合的な学習において, 見方や考え方 を養うことの導入を検討する必要があるだろう．見方や 考え方は, 知識や情報と相互に増進すると考えられ, 知 識や情報が増えるにしたがって見方や考え方の幅が広が るとともに奥深くなると考えられる，一方で，見方や考 え方は, 国語や算数・数学でも学習している. 理科, 社 会における見方や考え方の位置付けを考えるとともに, これらの教科間の連携についても検討の必要がある.い わゆる進学校を中心に, 高校までの学習の多くが入試対
策を念頭に置いて行われているとすれば，理科，社会は 暗記科目, 国語や算数・数学で考える力を養うという役 割分担が行われている可能性がある. しかしながら, 学 習指導要領では理科, 社会においても見方や考え方を養 うものとされており，小中高校における教育の現状や望 ましい方向性について，学習指導要領との整合性も含め て検討する必要がある.

大学側としては, 小中高校教育と大学教育とをつなぐ 入試の場において, このような学習指導要領の内容を認 識し, 入試の内容, 方法等について検討する必要がある.

初等・中等教育である小中高校教育, 高等教育である 大学・大学院教育, 社会における教育等は, 通常はそれ ぞれの段階ごとに検討が行われていると考えられる.し かしながら，教育を受ける，あるいは学習する側の人間 の側から考えると，これらの段階ごとの教育の有効性を 検討するためには，一貫して検討することが必要である. このような意味で, 本論のアンケート調査のように大学 生，社会人に，初等・中等教育，さらには高等教育の有 効性を問いかけるような視点が必要である.

\section{4. 環境教育と土木学の教育との関係}

本論文集は，土木学会教育論文集であり，環境教育と 土木学の教育との関係について考える. 土木学の内容と しては, 土木学会論文集の部門に挙げられている項目と し，各部門の小中高校における教科との対応，環境教育 との関連性について整理した（表-4）。既存の教科とし て対応するのは, 小学校の算数, 理科, 社会, 家庭科, 中学・高校の数学, 物理, 地理, 歴史, 技術家庭である と考えられた．環境教育に大きく関連するのは，部門B,

表-4 土木学会の查読部門と対応する初等，中等教育における教育内容およひ環境教育との関連性

\begin{tabular}{|c|l|c|c|}
\hline 部門 & \multicolumn{1}{|c|}{ 査読部門 } & $\begin{array}{c}\text { 対応す小中高校における } \\
\text { 教育内境教育に関 }\end{array}$ \\
連する部門)
\end{tabular}

注 1) 上段: 小学校, 下段: 中学・高校；2）○:環境教育に大きく関連する部門，○:環境教育に関連する部門， $\triangle$ : 環境教育に大きくは関連しないが, 何らかの形で関連すると思われる部門. 
$\mathrm{G}$ ，環境教育に関連するのは部門 $\mathrm{C}, \mathrm{D}$ ，環境教育に直接 は関連しないが何らかの形で関連すると考えられるのが 部門A，E，Fとした．表-4は，現在の環境教育が，水環境， 生態系, 廃棄物, エネルギ一等を中心とする内容となっ ていることを反映している. 今後は部門B, Gを中心に, 環境教育の分野との相互理解を促進寸るとともに, 他の 部門についても，既存の教科や環境教育への題材の提供 を考えていくことが必要である.

例えば，部門Aでは地震や風力発電，部門Cでは身近 な地盤，部門Dでは身近な交通や景観，部門Eでは身近 な建物, 部門Fでは身近な建設事業等がその内容として 考えられる. 数学, 理科等の教科では, 理論的枠組みの 基礎・応用の習得に力点が置かれてきたが，これらは土 木学から見た場合には基礎的分野であると考えられ，土 木学から見た応用とも言える内容を取り入れることも, 今後の方向性として検討すべき課題であろう。

\section{5. まとめ}

環境教育についての既往研究等のレビューの結果，小 学校から高等学校までの学習指導要領をまとめて検討し た研究や，大学生以上を対象に小中高校の環境に関する 教育の内容を検討した既往研究は見つからなかった. (1)既往研究等のレビュー，(2)小中高校における環境に ついの学習・経験内容についての大学生を対象とする アンケート調査結果, (3)アンケート調査結果の学習指 導要領の内容との比較検討, (4)土木学の教育と小中高 校における既存教科およひ環境教育との関連についての 検討の結果, 今後の学校教育を中心とする環境教育, 土 木学の教育について, 既存の指摘事項も含め, 次のよう な方向性が考えられた.

（1）環境教育を考える軸としては，公害と環境，関連 法・制度とカリキュラム・実践, 都市と地方, 学問 中心と目的中心, マクロ環境学とミクロ環境学等が あり, 学校教育における体系化も課題として指摘さ れている.

（2）カリキュラムに関しては, 既存教科単独カリキュラ ム群と複数教科による関連的カリキュラム群による 方法があり, 両者の有効性についてのさらなる検討 が必要である。

(3) 環境教育政策は，時代により異なる要因で策定され ているという考え方もあり，「持続可能な開発のた めの教育の 10 年」に関連する取り組みとしても, 情報関連技術の活用も含めて検討する必要がある.

(4) 学校教育と社会教育とを合わせて考えることも必要 で，社会教育においては NGO 等による活動の活用 も検討する必要がある.
(5) 初等, 中等教育における環境教育において, 学習指 導要領の内容を反映して，「見方や考え方を養う」 方法について検討する. 見方や考え方について十分 に学習・教育効果を得るためには, 教員の力量が問 われるとともに, 従来から課題として指摘されてい るように教材の作成, 選定が重要である.

(6) 学習指導要領の内容を小中高校生が理解することが 望ましいと考えられる，そのためには，例えば，小 中学生には学習指導要領の内容を分かり易く表現し た文章を作成する, 高校生には学習指導要領の本文 を提示して学習の永らいを理解させるといった方法 も有効であろう。

（7）今後予想される環境分野の重要性を考えると，総合 的な学習を含む社会, 理科教育等における環境教育 の小中高校における重要性が増加する. 小中高校に おいて, 従来, 暗記科目とも考えられていた社会, 理科教育に見方や考え方を養うことの導入について 検討する必要がある.

（8）小中高校において，理科，社会は暗記科目，国語や 算数・数学で考える力を養うという役割分担が行わ れている可能性があるが, 学習指導要領では理科, 社会においても見方や考え方を養うものとされてお り，小中高校における教育の現状や望ましい方向性 について，教科間の連携や学習指導要領との整合性 も含めて検討する必要があると考えられた。

(9) 大学側としては，小中高校における学習指導要領の 内容, 実際の学校における教育の内容について, 初 等中等教育と高等教育とをつなぐ入試の場等におい て検討方必要がある.

(10) 教育を受ける, あるいは学習する側の人間の側から 考えると，これらの段階ごとの教育の有効性を検討 するためには，一貫して検討することが必要であり， 本論のように大学生, 社会人に, 初等・中等教育, さらには高等教育の有効性を問いかけるような視点 が必要である.

(11) 土木学の教育と環境教育との関連については, 部門 $\mathrm{B}, \mathrm{G}$ は大きく関連し, 他の部門も含めて環境教育 や既存教科への題材提供等について必要性も含めて 検討すべきである.

謝辞 : 地球環境論、国際環境協力論を受講し、アンケー 卜調査に協力してくれた当時の文教大学国際学部・情報 学部学生の皆様に, ここに記して感謝致します.

\section{参考文献}

1) 都筑良明（2008）環境教育，日本教育制度学会編「教育改 革事典検証版 CD-ROM」（限定配布版）

2）都筑良明（2003a）地球環境論および国際環境計画論の履修 
学生に見る環境意識—アンケート調査結果のまとめ一，文 教大学国際学部紀要, 第 13 巻第 2 号, 89-131.

3) 都筑良明 (2003b) 大学における環境関連授業受講生の環境 意識の分析結果に基づく環境教育についての提案，第 31 回環境システム研究論文発表会講演集，土木学会，275-280.

4) 品田穣（1977）人間生活からみた環境教育, 環境情報科学, $6(2), 87-90$.

5) 日本環境協会（1984）昭和 58 年度「環境教育に関するカリ キュラム開発の実証的研究」報告書

6) 島津康男 (1978）環境学 (Envirronmentology) 一とくにその 大学院教育, 環境情報科学, 6(2), 112-116.

7) 沼田真（1982）環境教育のあり方と今後の方向，環境情報 科学, $11(4), 2-5$.

8) 小川潔（1982）日本における環境教育の流れと問題点，環 境情報科学, 11(4), 6-10.

9) 堀米富平（1982）小学校における環境教育の展望と実践, 環境情報科学, 11(4), 16-19.

10) 時乗晃（1982）学校裁量時間の活用による環境教育の実践, 環境情報科学, 11(4),26-29.

11) 市川寛（2003）タナゴの飼育活動から学校ビオトープ，そ してふるさと学習への発展と課題, 環境教育, Vol.10, No.1, $37-43$.

12）田中敏久（2003）○○と友達になろう！一身近な動植物と の継続的なかかわりを重視した体験的活動一, 環境教育, Vol.10, No.1,44-48.

13）石井信子（2003）地域や行政と共に取り組んだ公園作り, 環境教育, Vol.10, No.1,49-52.

14) 藤本勇二（2003）棚田に学ぶ子どもたち一地域にかかわり 自ら学ぶ子どもの育成一, 環境教育, Vol.10, No.1,53-61.

15) 神林哲平・森川靖・佐古順彦（2003）地域・学校特性及び 発達段階から夕た環境教育の実態一埼玉県内の公立小学校 を対象に一，環境教育，Vol.12,No.1,40-47.

16) 津田美子・津田智 (2002) 小学 6 年生における 5 教科 2 領 域を関連させた環境教育の実践，環境教育，Vol.11, No.2, 54 63.

17) 中村實（1982）琵琶湖を素材とした環境教育, 環境情報科 学, $11(4), 20-22$.

18) 目次清和（1982）NHK 学校放送番組「みどりの地球」を活 用して，環境情報科学，11(4),23-25.

19) 大越美香, 熊谷洋一（2002）学校ビオトープと緑地の自然環 境教育的利用に関する研究, 日本造園学会全国大会研究発 表論文集抄録, 79-79.

20) 高城英子・原子栄一郎（2003）アクションリサーチによる 中学 3 年生理科における環境教育の授業実践研究一生徒の 環境に対する意識の変化をとらえながら一, 環境教育, Vol.12, No.1,31-39.

21) 岸田恵津, 永田 智子 (2003) 教員養成系大学の調理実習に おける環境教育—教官の意識と指導の現状に関する調査一, (社) 日本家政学会第 54 回大会

22) 飯田範子,倉元綾子,鈴木真由子,内藤道子, 野田文子, 室雅子, 山口厚子, 吉井美奈子（2004）大学教育における家政教育力 リキュラムの現状と展望, 社団法人日本家政学会大会研究 発表要旨集, 103-103.

23) 近藤祐一郎・長瀬公秀・佐藤智史・江成敬次郎 (2004) 自 由記述文による総合的な学習の評価一環境に対する生徒の 意識調査をとおして一，環境教育，Vol.13,No.2,13-24.

24) 諫見泰彦 (2005) 那珂川流域を対象としたまちづくり学習 の実践, 日本デザイン学会研究発表大会概要集, 20-20.

25) 早㴊百合子，榎本洋祐，山末英嗣，奥村英之，石原慶一
（2005）循環型社会構築のためのエネルギー・環境教育の 影響と評価,第 1 回日本 LCA 学会研究発表会講演要旨集

26) 郷なおこ, 水野建樹, 津田祥子, 伊坪徳宏（2006）LCA 的思考 を導入した環境教育の実践, 日本 LCA 学会研究発表会講 演要旨集, 116-116.

27) 安田亜佐子, 山本 信次（2003）中学校における環境教育に 関する一考察，第 114 回日本林学会大会

28) 中尾俊雄（1977）社会科地理指導における環境教育, 環境 情報科学, 6(2), 25-30.

29) 藤岡達也（2002）高等学校の環境教育一日本環境教育学会 誌に掲載された論文から一, 環境教育, Vol.12, No.1,78-82.

30) 松井克行 (2002) 高等学校普通科における環境教育カリキ ユラム一学校設定科目「環境」の先行例としての「現代社 会」での実践一，環境教育，Vol.12,No.1,83-91.

31) 北田薰 (2002) 高等学校理数科における環境教育, 環境教 育, Vol.12, No.1,92-97.

32) 塩川哲雄（2002）高等学校における地域での環境教育活動, 環境教育, Vol.12, No.1,98.

33）橘淳治（2003）実験を通して考える生物と水質の関わりを 扱った環境教育一高校生物分野における化学的手法の導入 一，環境教育，Vol.13, No.1,52-56.

34) 田先崇志（2003）高等学校における環境教育の実践一学校 設定科目及び「総合的な学習の時間」での環境教育，環境 教育, Vol.13, No.1,57-63.

35) 荻原彰 (2003) 自然災害を通して地域の自然を学ぶ試み, 環境教育, Vol.13, No.1,64-64.

36) 福田直（2003）環境教育としての土の教材性に関する研究, 環境教育, Vol.13, No.1,3-12.

37) 大喜多祥子, 花崎憲子, 池田由起, 倉賀野妙子（2003）環境負 荷低減化に関する女子学生の意識と食行動, 日本調理科学 会大会研究発表要旨集, 124-124.

38) 加藤美由紀（2003）高校生物と高校倫理における「人間と 生物の関係」の捉え方，環境教育，Vol.12,No.2,24-32.

39）上杉良子，甲斐純子（2005）小学校家庭科カリキュラムの 研究一環境教育の視点からみた他教科等との関連について 一，第 47 回日本家庭科教育学会大会要旨集

40) 垂沢諒直（1977）小・中学校における環境教育の指導, 環 境情報科学, 6(2), 9-24.

41) 藤井信英 (2003) 高校生・大学生の森林認識と教科書記述 の検討，環境教育，Vol.12,No.2,15-23.

42) 土屋みさと，山口庸子（2007）たしかな目および家庭科教 科書にみられる環境関連掲載内容の比較, 第 2 回日本 LCA 学会研究発表会要旨集

43) 半谷高久（1977）大学院における環境教育, 環境情報科学, 6(2), $43-48$.

44) 綾野克俊 (1980) SUNY ・ ESF の大学院課程の環境科学教育, 環境情報科学, 9(4), 69-71.

45) 笹谷康之（2002）シンポジウムの報告と今後の課題, 環境 教育, Vol.11, No.2, 111-113.

46) 和田武 (2002) 大学環境教育研究会の現代的課題一持続可 能な社会の構築に向けて大学環境教育の量的拡大と質的向 上を一, 環境教育, Vol.11, No.2, 114-119.

47) 下羽友衛 (2002）大学の環境教育姿勢をめぐる基本的な論 点, 環境教育, Vol.11, No.2,119-127.

48) 高山進（2002）行動する学生を生み出す大学環境教育, 環 境教育, Vol.11, No.2, 128-133.

49) 諏訪博彦, 山本仁志, 岡田勇, 太田敏澄（2005）環境問題 解決のための環境教育に関する調査研究, 日本社会情報学 会第 20 回全国大会, 201-201. 
50) Uchiyama, H. (2004) Graduate schools and majors in Japanese national universities - in the view of higher education policy -, Joumal of Global Environment Engineering, Vol.10, 197-206.

51) 土木学会環境システム委員会環境システム学の体系化に関 する研究小委員会 (2005) 環境システム学: その深化と広 がり，土木学会論文集，1-10.

52) 谷口文章 (2003) 「パートナーシップによる環境教育・環 境学習の推進」調查報告概略, 環境教育, Vol.12, No.2, 33-36

53) 高橋 正弘, 井村 秀文（2004）日本における環境教育政策の 決定要因に関する研究，環境情報科学論文集 18，325-330

54) 梅村松秀（2006）持続可能な開発のための教育（ESD）と 地理教育 : 地理における環境問題の再考, 2006 年度日本地 理学会秋季学術大会

55）南澤信之（2005）教育における情報技術とコミュニケーシ ヨン，第 1 回横幹連合コンファレンス

56) 伊藤寿子（2005）環境教育・環境学習データベース総合整 備事業, CEIS 委託研究から(1), 環境情報科学, 34(2), 75-76.

57) 荻堂盛誉, 宮城博, 大城美香, 岡別府陽子, 小松徹史, 園田朗, 設 楽文朗 (2005) 「総合的な学習の時間」等への地球環境デ 一タ専用ブラウザ「バーチャルアース」利用について，情 報プロフェッショナルシンポジウム予稿集, 47-51.

58）小川潔（1992）環境教育の 20年, 環境情報科学, 21(2),2-6.

59) 山極隆（1992）学校における環境教育の基本理念, 環境情 報科学, $21(2), 7-10$.

60) 新広昭（1990）欧州における環境教育の現場を訪ねて，環 境問題トピックスシリーズ(35), 環境情報科学, 11(4),38-45.

61) 佐島群己, 中山和彦（1993）世界の環境教育, 地球時代の 環境教育 4, 国土社, 252p.

62）寺田卓三・ロバート L. ウォレス（2002）オーストラリ ア・ヴィクトリア州における後期中等教育段階の環境教育, 環境教育, Vol.11, No.2,4453.

63) 永川元 (2002) 高等学校理科教師における環境教育の実状 一神奈川県高等学校およびマレーシアの理科教師アンケー
卜調査結果より一，環境教育，Vol.11,No.2,87-95.

64) 王宗敏（2003）中国の小・中学校における環境教育の概況, 環境教育, Vol.12,No.2,73-78.

65) チャタジー公子（2004）インド，西ベンガル州の NGO 活 動一持続的農業プログラムの延長としての環境教育活動 ENREプロジェクトの試み一，環境教育, Vol.14, No.2, 162-168.

66) 朴恵淑（2006）世界の地理・環境教科書（教材）での「実 践的環境地理教育」ドイツ・中国・韓国の事例, 2006 年度 日本地理学会秋季学術大会

67) 蘇立, 山中英生, 上月康則（2007）日本及び中国における 環境教育の内容の変遷に関寸る比較分析一中国における地 理の学習指導要領と教科書記述を通して一, 土木学会論文 集 G, Vol.63, No.2,102-111.

68) 井元りえ（2003）日英の消費者教育と環境教育に関する比 較研究, 日本家庭科教育学会大会・例会・セミナ一研究発 表要旨集, $24-24$.

69) 大田正跲（1982）ディスカバリー・パークの環境教育, 環 境情報科学, 11(4),48-52.

70）阿部治（1990）環境教育再考, 環境情報科学, 11(4), 54-55.

71) 細木邦子 (1992) 環境教育の研究・実践のためのネットワ 一キングを考える一現状と展望一, 環境情報科学, 21 (2), 26-33.

72) 小川かほる, 都筑良明, 内山真義 (2003) 三番瀬問題を教 材とする市民の学び，第 37 回日本水環境学会年会

73) 国立教育政策研究所学習指導要領データベース作成委員会 (2003) 学習指導要領データベース, http://nierdb.nier.go.jp

74) 若林真一（1982）小中学校における環境教育の現状と問題, 環境情報科学, 11(4), 11-15.

75) 沼田眞（1992）巻頭言／ふたたび期待の深まる環境教育, 環境情報科学, 21 (2), 1-1.

\title{
DIRECTIONS OF ENVIRONMENTAL EDUCATION AND POSSIBILITIES OF CIVIL ENGINEERING EDUCATION IN SCHOOLS IN JAPAN
}

(2008.9.30 受付)

\author{
Yoshiaki TSUZUKI
}

Literature review on environmental education, questionnaire survey to university students in environment related classes on environmental education in their school days, from elementary school to high school, and investigation on the Official Course of Study of the Ministry of Education, Japan, of social and natural sciences at the time when the students were in elementary and high schools were conducted. Moreover, relationship of environmental education and existing subjects in elementary and secondary education with education of civil engineering are discussed. In the literature review on environmental education, existing researches on environmental education through elementary, middle and higher educations and in the society was found to be very scarce, however, considerations thorough these school stages were necessary from the view of growing and educating students. Some tasks on environmental education were found in the literatures including preparation of curriculums. Questionnaire results showed that the students have some appropriate knowledge and information on some environmental issues. However, such answers were rare that showed they have studied the watching and thinking ways and methods on nature and environment, which were described in the Official Course of Study of Japan. Therefore, some considerations on environmental education will be considered to be necessary including that both teachers and students should reassure the structures of the Course of Study, which includes growing the ways and methods on thinking and watching based on knowledge and information. For the relationship of the existing subjects and environmental education with education of civil engineering, most related in the categories of Japan Society of Civil Engineers are categories B and G. We should consider about the transfer of subjects and materials into elementary and secondary education including environmental education and other existing subjects. 